\title{
Evaluation of oral hygiene in school children from the eastern region of Wielkopolska
}

\author{
Teresa Matthews-Brzozowska', Agnieszka Sikorska', Kornela Cieślik², Arleta Głowacka', \\ Maja Matthews-Kozanecka ${ }^{3}$ \\ 1 Department of Orthopedics and Orthodontics, Poznan University of Medical Sciences, Poland \\ ${ }^{2}$ Department of Organization and Management in Health Care, Poznan University of Medical Sciences, Poland \\ ${ }^{3}$ Department of Social Sciences, Poznan University of Medical Sciences, Poland
}

ABSTRACT

Aim. The aim of the study was to assess oral health in school-age children on the basis of subjective and objective judgement, based on selected indicators.

Material and Methods. The study included students aged 10-13 years of primary and junior-high schools in the Mid Eastern region of Wielkopolska. Oral hygiene assessment was based on a prepared subjective questionnaireas well as on the basis of indicators: API P1.I, GI, including the sex of children.

Results. Of the 161 children of school age, most of them, as many as 145 showed attention to oral health, brushing teeth twice a day; some of them apply additional measures for oral hygiene - 39 children. In both sexes there were no deviations indicators examined. Between gender showed no difference, as confirmed statistically.

Conclusions. Oral hygiene in children with high health awareness rated positively, it should be emphasized that despite noninvasiveness the research group of respondents accounted for a small percentage of the children invited to the study, which points the need to undertake educational activities on a larger scale.

Keywords: girls and boys, indicators of bacterial plaque, oral hygiene, survey.

\section{Admission}

On the basis of the definition of the World Health Organization hygiene (Hygeinos - medicinal) is a branch of medicine, studying the environmental impacts on physical and mental health of men. Oral hygiene is an important part of the quality of life of every human being. The oral cavity is a different environment for every man hence the specific bacterial flora differs slightly between individuals. Plaque that lives in the mouth is a cohesive mass of yellowish-white color, exhibits cohesive structure, which can be removed by mechanical means. The clinical evaluation of visual supragingival and subgingival dental plaquemis performed during each dental visits, as in adolescent orthodontic patients [1-4]. Objective assessment is carried out using a variety of indicators such as the rate of platelet.: PI.I (Plague Index), API (Aproximal Plaque Index) indicators bleeding BI (Bleeding Index), SBI (Sulcus Bleeding Index), BOP (bleeding On Probing) and papillary bleeding index PBI (papillary bleeding Index), gingival index GI (gingival Index). Properly done oral treatments has positive influence on maintaining good health. Ailments associated with improper hygiene, left behind plaque and leftover food can cause tooth decay, gingivitis manifested by swelling, redness, bleeding, the same pain, which often discourage the patient to brush teeth. Fifteen years ago, literature reviews have shown that as a result of neglect oral hygiene comes to the deterioration of oral health $[5,6]$.

For many years, there has been conducted research on the ways and forms of patient education, effective learning hygienic habits and the use of additional gear 
oral hygiene, as a good oral hygiene contributes use additional gear [7-9]. We carried out research related to the use of various additional measures to enhance the cleanability of the oral cavity during orthodontic treatment, such as lotion: $0.2 \%$ chlorhexidine solution $[10,11]$.

\section{Aim}

The aim is to show the state of oral health of children based on subjective survey conducted using questionnaires and objective based on selected indicators.

\section{Material and Methods}

The subject studied were children of both sexes, of school age. The study invited students aged 10-13 years attending primary and secondary schools in the district of Koło, with over 1000 children. Schools' administration all primary and secondary schools have agreed to the announcement about the planned study, during meetings with parents. The parent/legal guardian of each student, having regard to the written information on the method and purpose of the study has given his written consent to the study. The study included only those students who participated in the study, that is, 161 children (boys and girls) in similar numbers four age groups: 10 years (group I - 43 people), 11 years (group II - 42 persons), 12 years old (group III -37 people), 13 years (group IV - 39 people). As a criterion to qualify taken into account the child's age and attending school in the district of Koło - eastern region of Wielkopolska. The study involved 89 girls and 72 boys - Table 1. For this project, a written consent was issued by the Bioethics Committee of the Medical University them in Poznan (Resolution No. 907/12).

During the illnesses' history interview, information was collected on the past or existing general diseases. They were asked about a history of injuries and treatments within the craniofacial, medications, dietary habits, type of diet. The survey questionnaires were analyzed only questions about the age and place of

Table 1. Test

\begin{tabular}{lccc}
\hline \multicolumn{1}{c}{ Age } & Girls & Boys & Together \\
\hline 10 years & $28(65.2 \%)$ & $15(34.8 \%)$ & $43(100 \%)$ \\
\hline 11 years & $27(64.3 \%)$ & $15(35.7 \%)$ & $42(100 \%)$ \\
\hline 12 years & $18(48.6 \%)$ & $19(51.4 \%)$ & $37(100 \%)$ \\
\hline 13 years & $16(41.1 \%)$ & $23(58.9 \%)$ & $39(100 \%)$ \\
\hline A total of & $89(55.3 \%)$ & $72(44.7 \%)$ & $161(100 \%)$ \\
\hline
\end{tabular}

residence of the test and the related oral hygiene. The responses were marked in the check boxes "yes"or "no" or supplemented eg.: additional funds for oral care. In a clinical study was conducted intraoral where drawn diagram and permanent dentition, and also rated oral health of children using selected indicators:

- Approximal plaque index (API) - used to assess the presence (denoted by a "+") or absence (denoted by "-") plaque in the interdental spaces. The survey was carried out in the upper quadrant of the arc buccal and III quadrant of the lower arch from the language. In total, we examined 10-12 interdental spaces for every child. The value of the calculated ratio API is given in percent: API = sum of interdental plaque divided by all test interdental spaces and the value multiplied times $100 \%$. The criterion for the assessment rate: $100-70 \%$ - poor/poor oral hygiene, $70-40 \%$ - average oral hygiene, $39-25 \%$ - good oral hygiene, $<25 \%$ - optimal oral hygiene.

- Indicator of bacterial plaque (PI.I) - used to evaluate the thickness of plaque localized around the neck of the tooth on the 4 surfaces (buccal / labial, linguistic, mesial, distal). The thickness of the plates was assessed in 4-point scale: 0 - no plates, 1 - thin layer of tiles adjacent to the cervical invisible to the naked eye, 2 - moderate accumulation of tiles visible to the naked eye, at the gingival margin, and (or) on the surface of the tooth and gingival pocket, 3 Extensive accumulation of deposits in the pocket, the gingiva and the tooth surface. The thickness of the plate was tested on six teeth $16,12,24,36,32$, 45. The values obtained from the four tooth surface were summed up and then divided by 4 , then PI.I all teeth were added together and then divided by 6 . At values $0-06$ oral hygiene was determined as a good, $0.7-1.8$ as the average, $1.9-3.0$ as bad.

- Gingival index (GI) - is used to evaluate inflammation gums. In the absence of visual signs of inflammation were labeled 0 . A value of 1 was determined by redness without bleeding during probing $2-$ to mark redness, swelling or hypertrophy of the gums while bleeding, 3 - with a pronounced inflammation of the trend to spontaneous bleeding. The assay was performed in four quadrants with a periodontal probe inserted into the interdental spaces, and the index value was calculated as follows: $\mathrm{GI}$ = number obtained from the survey divided by the number of spaces. The indicator values were interpreted as follows: 0 - healthy gums, $0.1-1.0-$ mild inflammation, 1.1 - 2.0 - moderate inflammation, $2.1-3.0$ - severe gingivitis. 
The study was conducted in the dental office with a sterile dental mirror, probe and periodontal probe.

From the data obtained a computerized database, which were statistically analyzed using statistical tests programs Statistica 10 and StatXact 8.

As the level of statistical significance adopted $a=$ 0.05 when $\mathrm{p}<\mathrm{a}$.

\section{Results}

The resulting slight differences in the rates of oral hygiene in girls and the boys proved to be statistically insignificant (Table 2). Analysis of the survey showed that the majority of children brushing teeth one or two times a day (81 girls and 64 boys), also did not reveal statistically significant differences with regard to gender. Out of 89 respondents, only 23 girls to apply additional measures for oral hygiene including 14 students mouthwash, 72 boys 16 apply additional measures for oral hygiene, including 12 students mouthwash, the result was also statistically insignificant.

\section{Discussion}

After conducting studies, it should be pointed good performance indicators of oral hygiene, also in both sexes. However, the fact that a small number of children from a very large group of invitees who have declared their willingness to participate in a non-invasive and painless tests, which strongly emphasized is disturbing. Given the age range further shows that the awareness of the benefits of this study did not increase with the age of the child, because the frequencies in age groups were similar. Regardless of this fact should be emphasized that every parent / legal guardian, taking into account the will of the child, has the right, at any stage of the research project, submitted in writing to withdraw consent to the study, and this decision can not be questioned [12]. Important, therefore, it seems to health promotion and health education, the ability to use offered to the public and research projects diagnosis, during which professional assessment of oral health is an aspect of prevention [13]. It is an opportunity to obtain information on the proper hygienization, the correction in terms of bad eating habits and others.

From the literature review carried out for many years it showed that patients treated with orthodontic who are under constant supervision of a physician or a dentist regularly, have better hygiene than patients not treated with orthodontic [14, 15]. Many years ago Glans et al [16] demonstrated the dependence of the state of the gums of the type and severity of crowding teeth; in his observations they pointed out that hygiene instruction has a influence on gingival bleeding index GBI. Assuming that dental abnormalities such as too crowded teeth are a common disorder of the dental arches in all populations, it is important that not only pedodonta first contact dentist with the child, but also a qualified dental hygienists or nurses pediatric, which is also highlighted in the foreign literature $[17,18]$. Orthodontic treatment usually lasts a few years, it is also a good time to educate the patient regarding hygienisation. Słomkowska and Jabłońska-Zrobek, [19] evaluated the impact of teaching on the level of hygiene plaque. They observed 30 patients (aged 10 to 14 years old) during the active phase of orthodontic treatment. The research preceded the professional instruction of oral hygiene $\mathrm{OHI}$ (Oral Hygiene Instruction). PI.I plaque index was used to measure the state of oral hygiene before test and after one month of treatment. The results clearly indicated a beneficial effect $\mathrm{OHI}$ instruction on oral hygiene, plaque index decreased in all patients. Constant oral hygiene instruction bring positive results in decrease of oral cavity Presented above results are encouraging; however we must stress that the whole project enveloped children who come from higher than average health awareness families.

Table 2. Summary of results indicators API PI.I and GI by gender

\begin{tabular}{|c|c|c|c|c|c|}
\hline $\begin{array}{c}\text { Population } \\
\text { sex } \\
\text { variable median } \\
\end{array}$ & \begin{tabular}{cc}
\multicolumn{2}{c}{ Mediana } \\
$\mathrm{N} \odot ;$ & $\mathrm{N} \lesssim$ \\
89 & 72 \\
\end{tabular} & \begin{tabular}{cc}
\multicolumn{2}{c}{ Minimum } \\
$\mathrm{N} \bigcirc ;$ & $\mathrm{N} \widehat{ठ}$ \\
89 & 72 \\
\end{tabular} & \begin{tabular}{cc}
\multicolumn{2}{c}{ Maximum } \\
$\mathrm{N} \bigcirc ;$ & $\mathrm{N} \bigcirc$ \\
89 & 72 \\
\end{tabular} & \begin{tabular}{cc}
\multicolumn{2}{c}{ Lower quartile } \\
$\mathrm{N} O ;$ & $\mathrm{N}{ }^{\lambda}$ \\
89 & 72 \\
\end{tabular} & 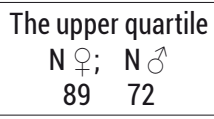 \\
\hline $\begin{array}{l}\text { Indicator } \\
\mathrm{API} \%\end{array}$ & 100 & $18,2 \quad 17,0$ & 100 & $75 \quad 81,7$ & $100 \quad 100$ \\
\hline $\begin{array}{l}\text { Indicator } \\
\text { Pl.I }\end{array}$ & 0,88 & 0,08 & 1,75 & $0,7 \quad 0,75$ & $1,04 \quad 1,2$ \\
\hline $\begin{array}{l}\text { Indicator } \\
\mathrm{GI}\end{array}$ & $0,08 \quad 0,05$ & 0,0 & $1,2 \quad 1,21$ & 0,0 & $0,25 \quad 0,2$ \\
\hline
\end{tabular}




\section{Conclusions}

Oral hygiene in school children, with a large pro-health awareness is good, but the study group accounted for about $16 \%$ of the invited students from the eastern region of Wielkopolska for non-invasive preventive examinations, which indicates a large need for education in this area.

\section{Acknowledgements}

Conflict of interest statement

The authors declare no conflict of interest.

\section{Funding sources}

There are no sources of funding to declare.

\section{References}

1. Ristic M, Vlahovic Svabic M, Sacic M, Zelic O. Clinical and microbiological effects off fixed orthodontic appliances on periodontal tissues in adolescents. Orthod Craniofacial Res. 2007;10:187-95.

2. Śmiech-Słomkowska G, Strzecki A. Wpływ leczenia aparatami stałymi na formowanie biofilmu w jamie ustnej. Forum Ortodontyczne. 2009;5(4):104-17.

3. Pellegrini $P$, Sauerwein R, Finlayson T, McLeod J, Covell DA, Maier $T$ et al. Plaque retention by self-ligating vs elastomeric orthodontic brackets: Quantitative comparison of oral bacteria and detection with adenosine triphosphate - driven bioluminescence. American Journal of Orthodontics and Dentofacial Orthopedics. 2009;135(4):426-28.

4. Martignon S, Ekstrand $\mathrm{KR}$, Lemos MI, Lozano MP, Higuera $\mathrm{C}$. Plaque, caries level and oral hygiene habits in young patients receiving orthodontic treatment. Community Dental Health. 2010;27:133-38.

5. Fornell ACh, Sköld-Larsson K, Hallgren A, Bergstrand F, Twetman S. Effect of a hydrophobic tooth coating on gingival health, mutans streptococci, and enamel demineralization in adolescents with fixed orthodontic appliances. Acta Odontol. Scand. 2002;60:37-41.

6. Laher A, Kroon J, Booyens SJ. Effectiveness of four manual toothbrushes in a cohort of patients undergoing fixed orthodontic treatment in an Academic Training Hospital. SADJ. 2003;58 (6):231-37.

7. Arici S, Alkan A, Arici N. Comparison of different toothbrushing protocols in poor-toothbrushing orthodontic patients. European Journal of Orthodontics. 2007;29:488-92.

8. Sharma NC, Lyle DM, Qaqish JG, Galustians J, Schuller R. Effect of a dental water jet with orthodontic tip on plaque and bleeding in adolescent patients with fixed orthodontic appliances. American Journal of Orthodontics and Dentofacial Orthopedics. 2008;133(4):565-71.

9. Park SY, Kim KH, Shin SY, Koo KT, Lee YM, Chung $\mathrm{CP}$, Seol YJ. Decontamination methods using a dental water jet and dental floss for microthreaded implant fixtures in regenerative periimplantitis treatment. Implant Dent. 2015;24(3):307-16.
10. Tufekci E, Casagrande ZA, Lindauer SJ, Fowler ChE, Williams KT. Effectiveness of an essential oil mouthrinse in improving oral health in orthodontic patients. Angle Orthodontist. 2008;78(2):294-98.

11. Levin L, Frankenthal S, Joseph L, Rozitsky D, Levi G, Machtei EE. Water jet with adjunct chlorhexidine gel for nonsurgical treatment of peri-implantitis. Quintessence Int. 2015;46(2):133-37.

12. Matthews-Kozanecka M. Zgoda na leczenie dziecka. Consent to treatment of the child. Art Dent. 2014;12(1):58-60.

13. Strużycka I, Małkowska A, Stopa J. Efektywne sposoby promocji zdrowia jamy ustnej. Czas. Stomat. 2005;58(6):392-96.

14. Opydo-Szymaczek J, Borysewicz-Lewicka M. Zmiany w mikroflorze jamy ustnej, jako potencjalny czynnik patogenny towarzyszący leczeniu ortodontycznemu. Nowa Stomatologia. 2003;2:93-96.

15. Czaplińska J, Cudziło D, Matthews-Brzozowska T. Assessment of oral health in patients with fixed appliances. Dent Med Probl. 2014;51(4):506-12.

16. Glans R, Larsson E, Ogaard B. Longitudinal changes in gingival condition in crowded and noncrowded dentitions subjected to fixed orthodontic treatment. Am J Orhod Dentofacial Orthop. 2003;124:679-82.

17. Honkala S, Honkala E, Al-Sahli N. Do life-or school-satisfaction and self-esteem indicators explain the oral hygiene habits of schoolchildren? Community Dent Oral Epidemiol. 2007;5:337-47.

18. Donna H, Donna S. Role of pediatric nurse practitioners in oral health care. Acad Pediatr. 2009;9:462-66.

19. Śmiech-Słomkowska G, Jabłońska-Zrobek J. The effect of oral health education on dental plaque development and the level of caries-related Streptococcus mutans and Lactobacillus spp. European Journal of Orthodontics. 2007;29:157-60.

20. Czaplińska J, Pobol-Aidi M, Aidi N, Matthews-Brzozowska T. The advisability of oral health education of patients treated with fixed orthodontic appliances. $\mathrm{Zdr}$ Pub. 2013;123(1):37-42.

21. Stodolak A, Fuglewicz A. Zapobieganie próchnicy zębów u dzieci i młodzieży oraz promocja zdrowia jamy ustnej - rola pracowników służby zdrowia. Medycyna Ogólna i Nauki o Zdrowiu. 2014;20(1):76-81.

22. Matthews-Brzozowska T, Czaplińska J, Cudziło D. Ocena wskaźników dziąsłowych u osób z wadami zgryzu w badaniach dwuletnich. Mag Stom. 2015;25(6):30-36.

Acceptance for editing: 2016-12-10 Acceptance for publication: 2016-12-22

Correspondence address: Kornela Cieślik Department of Organization and Management in Health Care Poznan University of Medical Sciences 11 Smoluchowskiego Street, 60-179 Poznan, Poland phone: +48605975693 